[Chem. Pharm. Bull.

35( 8 )3298-3304(1987)

\title{
Diarylheptanoids from the Rhizomes of Curcuma xanthorrhiza and Alpinia officinarum
}

\author{
Shin-IChi Uehara, ${ }^{a}$ IChiro Yasuda, ${ }^{a}$ KaZUyuki Akiyama, ${ }^{a}$ \\ Hiroshi MORITA, ${ }^{b}$ KOICHI TAKEYA ${ }^{b}$ \\ and HidEJI ITOKAWA ${ }^{*, b}$ \\ The Tokyo Metropolitan Research Laboratory of Public Health, ${ }^{a}$ 24-1, Hyakunincho 3-chome, \\ Shinjuku-ku, Tokyo 160, Japan and Tokyo College of Pharmacy, ${ }^{b}$ \\ 1432-1, Horinouchi, Hachioji-shi, Tokyo 192-03, Japan
}

(Received December 4, 1986)

\begin{abstract}
Five diarylheptanoids including two new compounds were isolated from the rhizomes of Curcuma xanthorrhiza (Zingiberaceae). The structures of the new compounds were determined to be octahydrocurcumin ((3S,5S)-1,7-bis(4-hydroxy-3-methoxyphenyl)-heptane-3,5-diol) (Ia) and (1))-1-hydroxy-1,7-bis(4-hydroxy-3-methoxyphenyl)-6-heptene-3,5-dione (II) on the basis of spectral and chemical evidence.

The absolute configurations of Ia and a new similar diarylheptanoid, (3R,5R)-1-(4-hydroxyphenyl)-7-phenylheptane-3,5-diol (VIa), isolated from the rhizomes of Alpinia officinarum (Zingiberaceae), were established by application of the exciton chirality rule.
\end{abstract}

Keywords diarylheptanoid; Curcuma xanthorrhiza; Alpinia officinarum; Zingiberaceae; (3S,5S)-1,7-bis(4-hydroxy-3-methoxyphenyl)-heptane-3,5-diol; (1 $\xi$ )-1-hydroxy-1,7-bis(4-hydroxy3-methoxyphenyl)-6-heptene-3,5-dione; (3R,5R)-1-(4-hydroxyphenyl)-7-phenylheptane-3,5-diol; exciton chirality rule; $C D$

The rhizomes of Temu Lawak, Curcuma xanthorrhiza (Zingiberaceae), have been utilized as a tonic in Indonesia and as a choleretic drug in Europe. As regards the chemical components of this plant, two diarylheptanoids have been reported. ${ }^{1)}$ In the present paper, we wish to report the isolation and structural elucidation of two new diarylheptanoids (Ia and II) and three known diarylheptanoids (dihydrocurcumin (III), hexahydrocurcumin (IV) and curcumin $(\mathrm{V}))$. In addition to these compounds, we wish to describe a new diarylheptanoid (VIa), obtained from the rhizomes of Alpinia officinarum (Zingiberaceae).

Each crude drug was extracted with methanol, and the extract was separated into the $n$ hexane- and chloroform-soluble fractions. Each chloroform-soluble fraction was chromatographed on silica gel to give Ia, II-V and VIa.

Compound Ia was obtained as colorless needles from benzene-chloroform, mp 132 $134^{\circ} \mathrm{C},[\alpha]_{\mathrm{D}}-18.5^{\circ}(c=0.26, \mathrm{EtOH})$. The molecular formula was established by the highresolution mass spectrum (MS). The infrared (IR) spectrum showed a strong and broad hydroxyl absorption at $3310 \mathrm{~cm}^{-1}$. The typical benzenoid absorption $(282 \mathrm{~nm})$, showing a bathochromic shift on addition of alkali, in the ultraviolet (UV) spectrum, and the positive coloration with diazo reagent, suggested the presence of a phenolic group. In the proton nuclear magnetic resonance $\left({ }^{1} \mathrm{H}-\mathrm{NMR}\right)$ spectrum, the signals of two methoxyl groups $(\delta 3.81)$ and 1,2,4-substituted benzene rings ( $2 \mathrm{H}$ each at $\delta 6.64, \mathrm{dd}, J=8,2 \mathrm{~Hz} ; 6.70, \mathrm{~d}, J=8 \mathrm{~Hz} ; 6.81$, $\mathrm{d}, J=2 \mathrm{~Hz}$ ) were observed. These findings and the base peak at $m / z 137$ in the MS indicated the presence of 4-hydroxy-3-methoxyphenyl groups and was confirmed by comparing the carbon-13 nuclear magnetic resonance $\left({ }^{13} \mathrm{C}-\mathrm{NMR}\right)$ data with those of analogous compounds. ${ }^{2,3)}$ Furthermore, the signals due to five methylenes $(\delta 1.58,2 \mathrm{H}, \mathrm{t}, J=6 \mathrm{~Hz}, \mathrm{H}-4$; 


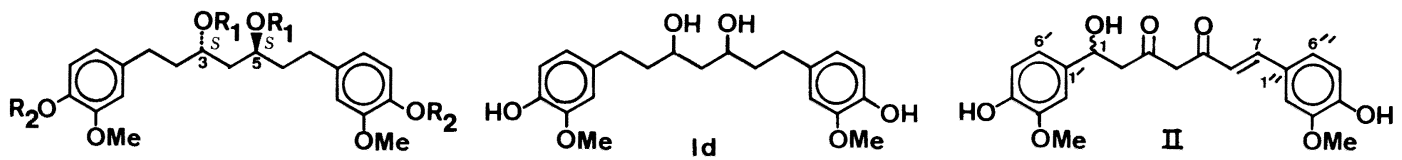

la $: \mathbf{R}_{\mathbf{1}}, \mathbf{R}_{\mathbf{2}}=\mathbf{H}$

$\mathrm{Ib}: \mathbf{R}_{\mathbf{1}}=\mathrm{H}, \mathbf{R}_{\mathbf{2}}=\mathrm{Me}$

$I c: R_{1}=-c o--N K_{M e}^{M e}, R_{2}=M e$

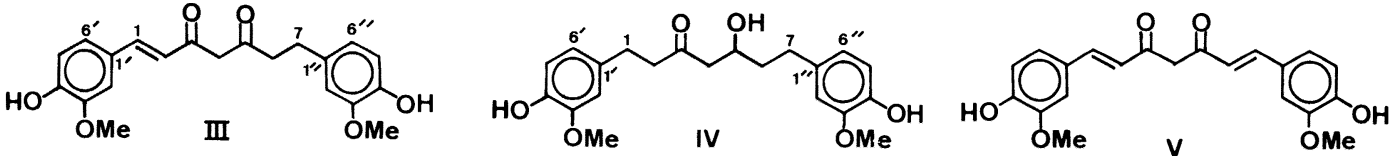<smiles>[R20]Oc1ccc(CC[C@@H]([R20])C[C@@H]([R20])CCc2ccccc2)cc1</smiles>

$\mathrm{VIa}: \mathbf{R}_{1}, \mathbf{R}_{2}=\mathrm{H}$

$\mathrm{VIb}: \mathrm{R}_{1}=\mathrm{H}, \mathrm{R}_{2}=\mathrm{Me}$<smiles>[R20][R]#P=[W]</smiles>

$\mathbf{R}_{\mathbf{2}}=\mathrm{Me}$

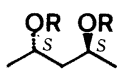

VIla, b

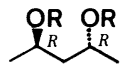

VII $a$, VIII $: R=H$

VIIb $, V I I I b: R=-C O-N<\frac{M e}{M e}$

Chart 1. The Chemical Structures of Ia-VIIIb

TABLE I. ${ }^{13}$ C-NMR Data for Ia-VIa

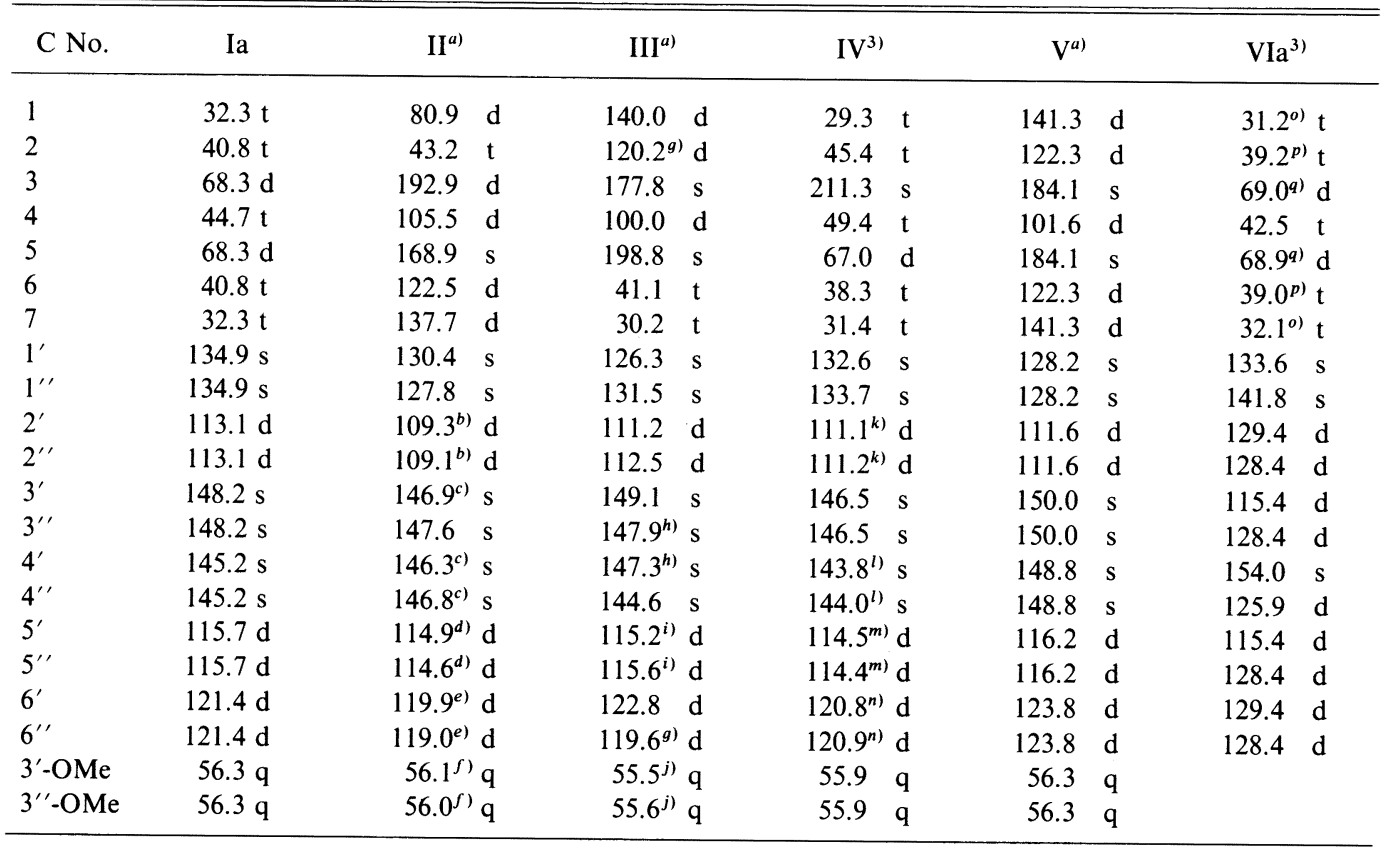

The measurements were made on a JEOL FX-270 spectrometer in acetone- $d_{6}$ (Ia, V and VIa), CDCl 3 (II and IV) or DMSO- $d_{6}$ (III) with tetramethylsilane as an internal reference, and are expressed in terms of ppm. $a$ ) Only the data of enol form are shown. $b-q)$ The assignments may be reversed. 
$1.62-1.78,4 \mathrm{H}, \mathrm{m}, \mathrm{H}-2,6 ; 2.41-2.76,4 \mathrm{H}, \mathrm{m}, \mathrm{H}-1,7)$, and two methine protons adjacent to a hydroxyl group $(\delta 3.85-3.97,2 \mathrm{H}, \mathrm{m}, \mathrm{H}-3,5)$ were observed in the ${ }^{1} \mathrm{H}-\mathrm{NMR}$ spectrum. The above data and the additivity ${ }^{4}$ of substituent group effects in the ${ }^{13} \mathrm{C}-\mathrm{NMR}$ spectrum indicate the position of two hydroxyl groups to be at C-3 and C-5. On the other hand, catalytic hydrogenation of curcumin (V) afforded octahydrocurcumin (Id). Compound Id was considered to be a mixture of $d l$ form and meso type on the basis of ${ }^{13} \mathrm{C}-\mathrm{NMR}$ spectral analysis $^{5)}$ and the presence of identical signals of Ia suggested that Ia is one of the stereoisomers of Id. On the basis of these chemical and spectral data, the structure of Ia was determined to be octahydrocurcumin (1,7-bis(4-hydroxy-3-methoxyphenyl)-heptane-3,5-diol).

The absolute configuration of the 3,5-hydroxyl groups was determined by application of the exciton chirality rule $^{6)}$ to the circular dichroism (CD) spectrum of the bis- $p$ dimethylaminobenzoate of a derivative of Ia. According to the exciton chirality rule, a pair of enantiomeric derivatives gives mirror-image $\mathrm{CD}$ curves and the absolute configuration of the enantiomers can be assigned from the sign of the maximum at longer wavelength. A positive sign indicates a clockwise spatial relationship between the interacting benzoate chromophores and vice versa. Prior to the examination, $(2 S, 4 S)-(+)$ - and $(2 R, 4 R)-(-)$-pentanediol (VIIa and VIIIa) were used as model compounds. They were converted into the bis- $p$ dimethylaminobenzoates (VIIb and VIIIb) in the usual manner. The CD spectra of VIIb and VIIIb provided mirror-image curves. That of VIIb showed a strong positive interaction peak at $318 \mathrm{~nm}$ crossing through zero at $305 \mathrm{~nm}$, indicating the absolute configuration to be $(2 S, 4 S)$ (Fig. 1). The configuration of VIIIb was thus $(2 R, 4 R)$. Hence, it has become apparent that the exciton chirality rule can be applied to determine the absolute configurations of these $1,3-$ dihydroxy compound.

In order to protect the phenolic hydroxyl groups, Ia was methylated with methyl iodide (Ib), and then converted into the bis- $p$-dimethylaminobenzoate (Ic). The CD spectrum of Ic showed a strong positive interaction peak at $318 \mathrm{~nm}$ crossing through zero at $307 \mathrm{~nm}$ (Fig. 1). Therefore, it is apparent that the 3,5-dihydroxyl groups of Ia are situated in clockwise spatial relationship and the absolute configuration of Ia is concluded to be $(3 S, 5 S)$.

Compound II was obtained as a yellow powder, mp 92.0-96.0 ${ }^{\circ} \mathrm{C},[\alpha]_{\mathrm{D}}+12.2^{\circ}(c=0.06$, $\mathrm{EtOH})$. The MS of II was similar to that of V. Dehydration of II gave V. The IR spectrum had a prominent band at $3525 \mathrm{~cm}^{-1}(\mathrm{OH})$. The UV absorption $(370 \mathrm{~nm})$, which shows a bathochromic shift on addition of alkali, suggested the presence of a phenolic group. In the ${ }^{13}$ C-NMR spectrum of II, the signal of 80.9 (d) showed the existence of an aliphatic secondary hydroxyl group. The ${ }^{1} \mathrm{H}-\mathrm{NMR}$ spectrum of II showed a 1,2,4-substituted benzene ring $(\delta 7.03$,

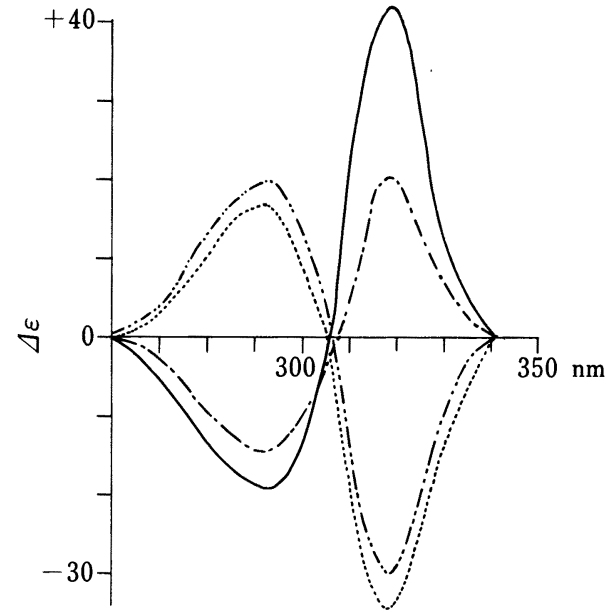

Fig. 1. Circular Dichroism (CD) Spectra of the Bis- $p$-dimethylaminobenzoate Derivatives of Ib (----), VIb (-----), VIIa $(-)$ and VIIIa (-----) 
$1 \mathrm{H}, \mathrm{dd}, J=8,2 \mathrm{~Hz} ; 6.90,1 \mathrm{H}, \mathrm{d}, J=8 \mathrm{~Hz} ; 7.00,4 \mathrm{H}$, br s), a pair of trans-olefinic protons $(\delta$ $7.30,1 \mathrm{H}, \mathrm{d}, J=16 \mathrm{~Hz} ; 6.44,1 \mathrm{H}, \mathrm{d}, J=16 \mathrm{~Hz}$ ), the proton on the central carbon of a $\beta$ diketone in its enol form ( $\delta 5.60)$ and two aromatic methoxyl groups ( $\delta 3.93$ and 3.95 ). The methine proton adjacent to a hydroxyl group $(\delta 5.39,1 \mathrm{H}, \mathrm{dd}, J=14,3.5 \mathrm{~Hz})$ was assigned to $\mathrm{H}-1$, because this proton was coupled with the protons at $\delta 2.93(1 \mathrm{H}, \mathrm{dd}, J=17,14 \mathrm{~Hz})$ and $2.65(1 \mathrm{H}, \mathrm{dd}, J=17,3.5 \mathrm{~Hz})$ which were assigned as methylene protons at $\mathrm{H}-2$. Thus, the position of the hydroxyl group was assigned as C-1. On the basis of these chemical and spectral properties, the structure of II was determined to be 1-hydroxy-1,7-bis(4-hydroxy-3methoxyphenyl)-6-heptene-3,5-dione. The absolute configuration of the hydroxyl group is now under investigation.

Compound III was obtained as yellow needles, $\mathrm{mp} 178.0^{\circ} \mathrm{C}$, and was identified as dihydrocurcumin (1,7-bis(4-hydroxy-3-methoxyphenyl)-1-heptene-3,5-dione), which has already been isolated from Curcuma longa, by comparing its spectral data with those of an authentic specimen. ${ }^{7)}$ The structure of this compound was confirmed by the catalytic hydrogenation of V to III.

Compound IV was obtained as a colorless oil and was identified as hexahydrocurcumin (5-hydoxy-1,7-bis(4-hydroxy-3-methoxyphenyl)-3-heptanone), which has already been isolated from Zingiber officinale and Alpinia officinarum, by comparing its spectral data with those of an authentic specimen. ${ }^{8-10}$ ) The structure of this compound was confirmed by the catalytic hydrogenation of V to IV. Since IV is optically inactive, it seems to be a racemate.

Compound $\mathrm{V}$ was obtained as yellow needles, $\mathrm{mp} 183.0^{\circ} \mathrm{C}$, and was identified as curcumin (1,7-bis(4-hydroxy-3-methoxyphenyl)-1,6-heptadiene-3,5-dione), which has already been isolated from this plant, ${ }^{1)}$ by direct comparison with an authentic sample, isolated from Curcuma longa.

Compound VIa, colorless needles, mp 109.0-111.0 ${ }^{\circ} \mathrm{C},[\alpha]_{\mathrm{D}}+8.3^{\circ}\left(c=0.39, \mathrm{CHCl}_{3}\right)$, obtained from the rhizomes of Alpinia officinarum, was isolated as a compound similar to Ia, as judged from the spectral properties. The molecular formula was established by highresolution MS. The IR spectrum had a prominent band at $3600 \mathrm{~cm}^{-1}(\mathrm{OH})$. The typical benzenoid UV absorption $(275 \mathrm{~nm})$, showing a bathochromic shift on addition of alkali, suggested the presence of a phenolic group. Furthermore, the signals of three carbons $(\delta 68.9$, 69.0 , each $\mathrm{d} ; 154.0 \mathrm{~s}$ ) in ${ }^{13} \mathrm{C}-\mathrm{NMR}$ showed the existence of two aliphatic secondary hydroxyl groups and one phenolic hydroxyl group. As regards the substitution pattern of the two aromatic rings, a $p$-substituted benzene ring and a monosubstituted benzene ring were indicated by the ${ }^{1} \mathrm{H}-\mathrm{NMR}$ signals at $\delta 6.73(2 \mathrm{H}, \mathrm{d}, J=8.5 \mathrm{~Hz}), 7.03(2 \mathrm{H}, \mathrm{d}, J=8.5 \mathrm{~Hz})$ and $7.18-7.29(5 \mathrm{H}, \mathrm{m})$. These findings and the MS fragment peaks at $m / z 91$ and 107 suggested the presence of phenyl and 4-hydroxyphenyl groups. The signals due to five methylenes $(\delta$ $1.59,2 \mathrm{H}, \mathrm{t}, J=6 \mathrm{~Hz}, \mathrm{H}-4 ; 1.66-1.79,4 \mathrm{H}, \mathrm{m}, \mathrm{H}-2,6 ; 2.50-2.87,4 \mathrm{H}, \mathrm{m}, \mathrm{H}-1,7)$ and two methine protons adjacent to hydroxyl groups $(\delta 3.84-3.95,2 \mathrm{H}, \mathrm{m}, \mathrm{H}-3,5)$ were observed in the ${ }^{1} \mathrm{H}$-NMR spectrum. The two aliphatic secondary hydroxyl groups assigned to $\mathrm{C}-3$ and $\mathrm{C}$ 5 were confirmed by comparing the ${ }^{13} \mathrm{C}-\mathrm{NMR}$ data of VIa with those of Ia. On the basis of these spectral data, VIa was concluded to be 1-(4-hydroxyphenyl)-7-phenylheptane-3,5-diol.

The absolute configurations of the 3,5-hydroxyl groups were determined in the same manner as with Ia. Compound VIa was methylated with methyl iodide (VIb), and then converted into the bis-p-dimethylaminobenzoate (VIc). The CD spectrum of VIc showed a strong negative interaction peak at $318 \mathrm{~nm}$ crossing through zero at $306 \mathrm{~nm}$ (Fig. 1). Therefore, it became apparent that the 3,5-hydroxyl groups of VIa are situated in a counterclockwise spatial relationship and the absolute configuration of VIa is concluded to be $(3 R, 5 R)$.

Many diarylheptanoids have been isolated from Curcuma xanthorrhiza and Alpinia officinarum. ${ }^{1-3,10,11)}$ We have now added three new diarylheptanoids to this group. 


\section{Experimental}

All melting points were recorded on a Yazawa micro melting point apparatus and are uncorrected. Spectral data were obtained on the following instruments; UV spectra on a Hitachi 320, optical rotation on a JASCO DIP-181, CD on a JASCO J-500C, IR on a Hitachi EPI-G3 and MS on a JEOL JMS D-300 (at an ionizing potential of $70 \mathrm{eV}$ ). ${ }^{1} \mathrm{H}-$ and ${ }^{13} \mathrm{C}$-NMR spectra were measured on a JEOL FX-270 (at $269.65 \mathrm{MHz}$ and $67.8 \mathrm{MHz}$, respectively). Chemical shifts are given on the $\delta$ scale with tetramethylsilane as an internal standard. $(2 S, 4 S)-(+)$-Pentanediol was purchased from Aldrich Co. and $(2 R, 4 R)-(-)$-pentanediol from Wako Pure Chemical Industries Co. Diazobenzenesulfonic acid in water was used as the diazo reagent. $p$-Dimethylaminobenzoyl chloride was prepared as described in the literature. ${ }^{12)}$ Column chromatography was carried out on Silica gel 60 (230-400 mesh ASTM, Merck) unless otherwise stated. Thin layer chromatography (TLC) and preparative TLC were performed on Silica gel $60 \mathrm{~F}_{254}$ precoated plate (Merck). The developing solvent for TLC was benzene-AcOEt $(1: 1)$ unless otherwise stated, and detection was carried out by UV irradiation $(254 \mathrm{~nm})$ and spraying $10 \% \mathrm{H}_{2} \mathrm{SO}_{4}$ followed by heating.

Extraction and Isolation-Curcuma xanthorrhiza: The rhizomes of Curcuma xanthorrhiza were collected in 1982 , in Ciandur, Indonesia. The crude drug $(400 \mathrm{~g})$ was extracted three times with methanol. The concentrated methanol extract $(60 \mathrm{~g})$ was diluted with water to about $10 \%$ aq. $\mathrm{MeOH}$ and then successively partitioned with $n$ hexane and $\mathrm{CHCl}_{3}$ three times each. Evaporation of the $\mathrm{CHCl}_{3}$-soluble fraction left a brown oil $(16 \mathrm{~g})$. $\mathrm{The}_{\mathrm{CHCl}}$ extract was subjected to column chromatography on silica gel (silica gel for dry column chromatography, ICN) with a $\mathrm{CHCl}_{3}-\mathrm{MeOH}$ gradient system. Repeated chromatography of each fraction (silica gel column chromatography and preparative TLC) afforded Ia $(20 \mathrm{mg})$, II $(10 \mathrm{mg})$, III (10 mg), IV $(50 \mathrm{mg})$ and V $(250 \mathrm{mg})$.

Alpinia officinarum: The rhizomes $(10 \mathrm{~kg})$ of Alpinia officinarum were extracted three times with methanol. The methanol extract was diluted with water to about $10 \%$ aq. $\mathrm{MeOH}$ and partitioned with $n$-hexane. The aq. $\mathrm{MeOH}$ layer was further concentrated and partitioned with $\mathrm{CHCl}_{3}$. Evaporation of the $\mathrm{CHCl}_{3}$-soluble fraction left a brown oil $(518 \mathrm{~g})$. The $\mathrm{CHCl}_{3}$ extract $(100 \mathrm{~g})$ was subjected to column chromatography on silica gel (silica gel for dry column chromatography, ICN) with a $\mathrm{CHCl}_{3}-\mathrm{MeOH}$ gradient system. Repeated chromatography of each fraction (silica gel column chromatography and preparative TLC) afforded VI (100 mg).

(3S,5S)-1,7-Bis(4-hydroxy-3-methoxyphenyl)-heptane-3,5-diol (Ia): Colorless needles. mp 132-134 ${ }^{\circ} \mathrm{C},[\alpha]_{\mathrm{D}}$ $-18.5^{\circ}\left(c=0.26\right.$, EtOH). UV $\lambda_{\max }^{\mathrm{EtOH}} \mathrm{nm}(\varepsilon): 225$ (21000), 282 (8600). UV $\lambda_{\max }^{\mathrm{EtOH}+\mathrm{NaOH}} \mathrm{nm}: 243,296$ (bathochromic shift). Diazo reagent: positive (orange). MS $m / z(\%): 376\left(\mathrm{M}^{+}, 7\right.$, Calcd for $\mathrm{C}_{21} \mathrm{H}_{28} \mathrm{O}_{6}, 376.1883$; Found 376.1858), 358 (11), 340 (3), 151 (7), 150 (5), 138 (24), 137 (100). IR (KBr) cm cm $^{-1}: 3460,3310$ (br), 2940, 1600, 1515, 1460, 1430, $1350,1270,1225, \mathrm{i} 200,1155,1070,1040 .{ }^{1} \mathrm{H}-\mathrm{NMR}$ (acetone- $\left.d_{6}\right): 1.58(2 \mathrm{H}, \mathrm{t}, J=6 \mathrm{~Hz}), 1.62-1.78(4 \mathrm{H}, \mathrm{m}), 2.41-$ $2.76(4 \mathrm{H}, \mathrm{m}), 3.81(6 \mathrm{H}, \mathrm{s}), 3.85-3.97(2 \mathrm{H}, \mathrm{m}), 6.64(2 \mathrm{H}, \mathrm{dd}, J=8,2 \mathrm{~Hz}), 6.70(2 \mathrm{H}, \mathrm{d}, J=8 \mathrm{~Hz}), 6.81(2 \mathrm{H}, \mathrm{d}, J=2 \mathrm{~Hz})$, $7.45\left(1 \mathrm{H}\right.$, brs, disappeared on addition of $\left.\mathrm{D}_{2} \mathrm{O}\right)$. TLC: $R f 0.1$.

Methylation of $\mathrm{Ia}$ to $\mathrm{Ib}^{13)}$ _ A solution of $\mathrm{Ia}(3 \mathrm{mg})$ in dry acetone $(1 \mathrm{ml})$ with anhydrous potassium carbonate $(10 \mathrm{mg})$ and methyl iodide $(0.5 \mathrm{ml})$ was refluxed at $60-70^{\circ} \mathrm{C}$ for about $6 \mathrm{~h}$. The reaction mixture was filtered, and the residue was washed thoroughly with acetone. The combined filtrate was evaporated in vacuo and the residue was chromatographed on a silica gel column (benzene-AcOEt $=1: 1$ ) and further purified by preparative TLC. The purified product was recrystallized from benzene to give colorless needles $(\mathrm{Ib}, 2 \mathrm{mg})$, mp $95-96^{\circ} \mathrm{C},[\alpha]_{\mathrm{D}}-9.4^{\circ}$ $(c=0.1, \mathrm{EtOH}) . \mathrm{MS} m / z(\%): 404\left(\mathrm{M}^{+}, 8\right), 386(14), 368(9), 177(12), 165$ (7), $152(31), 151(100), 137(8) .{ }^{1} \mathrm{H}-\mathrm{NMR}$ $\left(\mathrm{CDCl}_{3}\right) \delta: 1.68(2 \mathrm{H}, \mathrm{t}, J=5.5 \mathrm{~Hz}), 1.70-1.91(4 \mathrm{H}, \mathrm{m}), 2.27\left(2 \mathrm{H}\right.$, br s, disappeared on addition of $\left.\mathrm{D}_{2} \mathrm{O}\right), 2.50-2.79$ $(4 \mathrm{H}, \mathrm{m}), 3.85(6 \mathrm{H}, \mathrm{s}), 3.87(6 \mathrm{H}, \mathrm{s}), 3.94-4.06(2 \mathrm{H}, \mathrm{br} \mathrm{m}), 6.72(2 \mathrm{H}, \mathrm{d}, J=2 \mathrm{~Hz}), 6.73(2 \mathrm{H}, \mathrm{dd}, J=8,2 \mathrm{~Hz}), 6.80(2 \mathrm{H}, \mathrm{d}$, $J=8 \mathrm{~Hz})$.

Bis-p-dimethylaminobenzoate (Ic) of Ib-The mixture of $\mathrm{Ib}(2 \mathrm{mg})$ and excess $p$-dimethylaminobenzoyl chloride in $1 \mathrm{ml}$ of dry pyridine was heated for $30 \mathrm{~min}$ under reflux. After complete removal of pyridine in vacuo, the residue was purified by column chromatography (benzene: $\mathrm{AcOEt}=5: 1$ ) and preparative TLC (benzene: $\left.\mathrm{CHCl}_{3}: \mathrm{CH}_{3} \mathrm{CN}=2: 1: 1\right)$ to give Ic as a colorless oil $(1 \mathrm{mg}),[\alpha]_{\mathrm{D}}+36^{\circ}(c=0.07, \mathrm{EtOH})$. UV $\lambda_{\max }^{\mathrm{EtOH}} \mathrm{nm}(\varepsilon): 229$ (30000), 311 (50000). CD $(c=0.0004, \mathrm{EtOH}): \Delta \varepsilon=+20$ (318) (positive maximum), $\Delta \varepsilon=0(307), \Delta \varepsilon=-15(292)$ (negative maximum). MS $m / z(\%): 698\left(\mathrm{M}^{+}, 4\right), 533$ (7), 368 (17), 204 (27), $177(26), 165(43), 164$ (47), 151 (80), 148 (100). ${ }^{1} \mathrm{H}-\mathrm{NMR}\left(\mathrm{CDCl}_{3}\right) \delta: 1.80-2.17(6 \mathrm{H}, \mathrm{m}), 2.50-2.72(4 \mathrm{H}, \mathrm{m}), 3.01(12 \mathrm{H}, \mathrm{s}), 3.79(6 \mathrm{H}, \mathrm{s}), 3.82(6 \mathrm{H}, \mathrm{s}), 5.25(2 \mathrm{H}$, br m), $6.57(4 \mathrm{H}, \mathrm{d}, J=9 \mathrm{~Hz}), 6.60-6.70(4 \mathrm{H}, \mathrm{m}), 6.73(2 \mathrm{H}, \mathrm{d}, J=8.5 \mathrm{~Hz}), 7.83(4 \mathrm{H}, \mathrm{d}, J=9 \mathrm{~Hz})$.

Bis-p-dimethylaminobenzoates (VIIb and VIIIb) of VIIa and VIIIa-The method described above was employed with $100 \mathrm{mg}$ of VIIa and VIIIa. Each product was purified by column chromatography (benzene $: \mathrm{AcOEt}=$ $5: 1)$ and recrystallized from EtOH to give VIIb and VIIIb as colorless needles.

VIIb: mp $125-126^{\circ} \mathrm{C},[\alpha]_{\mathrm{D}}+349^{\circ}(c=0.205, \mathrm{EtOH}) . \mathrm{UV} \lambda_{\max }^{\mathrm{EtOH}} \mathrm{nm}(\varepsilon): 311 \mathrm{~nm}(53100) . \mathrm{CD}(c=0.00025, \mathrm{EtOH})$ : $\Delta \varepsilon=+41.4$ (318) (positive maximum), $\Delta \varepsilon=0$ (305), $\Delta \varepsilon=-19.5$ (292) (negative maximum). MS $m / z(\%): 398\left(\mathbf{M}^{+}\right.$, 13), 234 (18), 233 (19), $166(14), 165$ (100), 164 (89), 149 (16), $148(64) .{ }^{1} \mathrm{H}-\mathrm{NMR}\left(\mathrm{CDCl}_{3}\right) \delta: 1.37(6 \mathrm{H}, \mathrm{d}, J=6 \mathrm{~Hz})$, $2.05(2 \mathrm{H}, \mathrm{t}, J=6 \mathrm{~Hz}), 3.01(12 \mathrm{H}, \mathrm{s}), 5.24(2 \mathrm{H}, \mathrm{tq}, J=6,6 \mathrm{~Hz}), 6.59(4 \mathrm{H}, \mathrm{d}, J=9 \mathrm{~Hz}), 7.85(4 \mathrm{H}, \mathrm{d}, J=9 \mathrm{~Hz})$.

VIIIb: mp $123-125^{\circ} \mathrm{C},[\alpha]_{\mathrm{D}}-302^{\circ}(c=0.194, \mathrm{EtOH})$. UV $\lambda_{\max }^{\mathrm{EtOH}} \mathrm{nm}(\varepsilon): 311(54100) . \mathrm{CD}(c=0.00023, \mathrm{EtOH})$ : $\Delta \varepsilon=-34.8$ (318) (negative maximum), $\Delta \varepsilon=0$ (305), $\Delta \varepsilon=+16.8$ (292) (positive maximum). The MS and ${ }^{1} \mathrm{H}-\mathrm{NMR}$ data for VIIIb were identical with those for VIIb. 


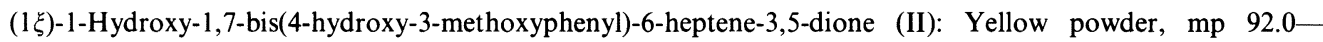
$96.0^{\circ} \mathrm{C},[\alpha]_{\mathrm{D}}+12.2^{\circ}(c=0.06, \mathrm{EtOH}) . \mathrm{UV} \lambda_{\max }^{\mathrm{EtOH}} \mathrm{nm}(\varepsilon): 370(56000), 283$ (18000), 260 (21000), 230 (sh). UV $\lambda_{\max }^{\mathrm{EIOH}+\mathrm{NaOH}} \mathrm{nm}: 452,286,252$ (bathochromic shift). MS $m / z(\%): 368\left(\mathrm{M}^{+}-18,33\right), 350\left(\mathrm{M}^{+}-18 \times 2,26, \mathrm{Calcd}\right.$ for $\mathrm{C}_{21} \mathrm{H}_{18} \mathrm{O}_{5}, 350.1152$; Found 350.1147), 191 (30), 190 (43), 177 (100), 150 (37), 145 (49), 137 (50). IR $\left(\mathrm{CHCl}_{3}\right)$ $\mathrm{cm}^{-1}: 3525,2900,2850,1650,1620,1600,1560,1460,1375,1325,1260,1120,1000,965 .{ }^{1} \mathrm{H}-\mathrm{NMR}\left(\mathrm{CDCl}_{3}\right) \delta: 2.65$ $(1 \mathrm{H}, \mathrm{dd}, J=17,3.5 \mathrm{~Hz}), 2.93(1 \mathrm{H}, \mathrm{dd}, J=17,14 \mathrm{~Hz}), 3.93(3 \mathrm{H}, \mathrm{s}), 3.95(3 \mathrm{H}, \mathrm{s}), 5.39(1 \mathrm{H}, \mathrm{dd}, J=14,3.5 \mathrm{~Hz}), 5.60(1 \mathrm{H}$, s), $5.80\left(1 \mathrm{H}\right.$, br s, disappeared on addition of $\left.\mathrm{D}_{2} \mathrm{O}\right), 5.86\left(1 \mathrm{H}\right.$, br s, disappeared on addition of $\left.\mathrm{D}_{2} \mathrm{O}\right), 6.44(1 \mathrm{H}, \mathrm{d}$, $J=16 \mathrm{~Hz}), 6.90(1 \mathrm{H}, \mathrm{d}, J=8 \mathrm{~Hz}), 7.00(4 \mathrm{H}, \mathrm{br} \mathrm{s}), 7.03(1 \mathrm{H}, \mathrm{dd}, J=8,2 \mathrm{~Hz}), 7.30(1 \mathrm{H}, \mathrm{d}, J=16 \mathrm{~Hz})$. TLC:Rf 0.2 .

Dehydration of II to $\mathrm{V}-\mathrm{II}(2 \mathrm{mg})$ was heated at $130^{\circ} \mathrm{C}$ under reduced pressure $(<15 \mathrm{mmHg})$ for $10 \mathrm{~h}$. After cooling, it was subjected to preparative TLC to give yellow needles $(1.5 \mathrm{mg})$, which were identical with $\mathrm{V}$ on the basis of mixed melting point determination and TLC, MS and ${ }^{1} \mathrm{H}-\mathrm{NMR}$ comparisons.

Dihydrocurumin (III): Yellow needles, mp $178.0^{\circ} \mathrm{C}$. UV $\lambda_{\max }^{\mathrm{EtOH}} \mathrm{nm}(\varepsilon): 376(32000), 285(7500), 260$ (7900), 230 (sh). MS $m / z(\%): 370\left(\mathrm{M}^{+}, 11\right.$, Calcd for $\mathrm{C}_{21} \mathrm{H}_{22} \mathrm{O}_{6}, 370.1415$; Found 370.1426), $352(10), 233(6), 219(11), 191(24)$, 193 (4), 177 (56), 150 (32), 137 (100). IR (KBr) cm $\mathrm{cm}^{-1}: 3400,1635,1610,1515,1435,1410,1280,1240,1200,1160$, 1120, 1035, 860, 820. ${ }^{1} \mathrm{H}$-NMR (DMSO-d $) \delta: 2.68(2 \mathrm{H}, \mathrm{m}), 2.78(2 \mathrm{H}, \mathrm{m}), 3.74(3 \mathrm{H}, \mathrm{s}), 3.82(3 \mathrm{H}, \mathrm{s}), 5.78(1 \mathrm{H}, \mathrm{s}), 6.65$ $(3 \mathrm{H}, \mathrm{m}), 6.81(2 \mathrm{H}, \mathrm{m}), 7.11(1 \mathrm{H}, \mathrm{d}, J=7.5 \mathrm{~Hz}), 7.29(1 \mathrm{H}, \mathrm{s}), 7.48(1 \mathrm{H}, \mathrm{d}, J=15.5 \mathrm{~Hz}), 8.69(1 \mathrm{H}, \mathrm{s}$, disappeared on addition of $\left.\mathrm{D}_{2} \mathrm{O}\right), 9.60\left(1 \mathrm{H}, \mathrm{s}\right.$, disappeared on addition of $\left.\mathrm{D}_{2} \mathrm{O}\right)$. TLC: $R f 0.5$.

Hexahydrocurcumin (IV): Colorless oil, $[\alpha]_{\mathrm{D}} 0^{\circ}\left(c=0.2, \mathrm{CHCl}_{3}\right)$. UV $\lambda_{\max }^{\mathrm{EtOH}} \mathrm{nm}(\varepsilon): 282(7400), 228(15600)$. MS $m / z(\%): 374\left(\mathrm{M}^{+}, 6\right.$, Calcd for $\mathrm{C}_{21} \mathrm{H}_{26} \mathrm{O}_{6}, 374.1727$; Found 374.1706), 356 (9), $138(17), 151(4), 150$ (7), $137(100)$. IR $\left(\mathrm{CHCl}_{3}\right) \mathrm{cm}^{-1}: 3540,3005,2940,2400,1705,1610,1510,1460,1430,1370,1270,1150,1125,1040,930 .{ }^{1} \mathrm{H}-\mathrm{NMR}$ $\left(\mathrm{CDCl}_{3}\right) \delta: 1.50-1.87(2 \mathrm{H}, \mathrm{m}), 2.40-2.88(8 \mathrm{H}, \mathrm{m}), 3.85(3 \mathrm{H}, \mathrm{s}), 3.86(3 \mathrm{H}, \mathrm{s}), 3.92-4.08(1 \mathrm{H}, \mathrm{m}), 5.55(2 \mathrm{H}$, br s, disappeared on addition of $\left.\mathrm{D}_{2} \mathrm{O}\right), 6.60-6.74(4 \mathrm{H}, \mathrm{m}), 6.82(2 \mathrm{H}, \mathrm{d}, J=8 \mathrm{~Hz})$. TLC: $R f 0.3$.

Curcumin (V): Yellow needles, $m p 183^{\circ} \mathrm{C}$. UV $\lambda_{\max }^{\mathrm{EtOH}} \mathrm{nm}(\varepsilon): 420(57000)$. MS m/z (\%): $368\left(\mathrm{M}^{+}, 25\right), 350$ $\left(\mathrm{M}^{+}-18,32\right.$, Calcd for $\mathrm{C}_{21} \mathrm{H}_{18} \mathrm{O}_{5}, 350.1152$ : Found 350.1152), 191 (37), 190 (57), 177 (100), 150 (40), 145 (82), 137 (58). IR (KBr) cm ${ }^{-1}: 3450,1630,1605,1510,1430,1280,1235,1205,1185,1160,1120,1030,963 .{ }^{1} \mathrm{H}-\mathrm{NMR}$ (acetone$\left.d_{6}\right): 3.92(6 \mathrm{H}, \mathrm{s}), 5.97(1 \mathrm{H}, \mathrm{s}), 6.70(2 \mathrm{H}, \mathrm{d}, J=16 \mathrm{~Hz}), 6.89(2 \mathrm{H}, \mathrm{d}, J=8 \mathrm{~Hz}), 7.18(2 \mathrm{H}, \mathrm{dd}, J=8,2 \mathrm{~Hz}), 7.32(2 \mathrm{H}, \mathrm{d}$, $J=2 \mathrm{~Hz}), 7.60(2 \mathrm{H}, \mathrm{d}, J=16 \mathrm{~Hz}), 8.25\left(2 \mathrm{H}\right.$, br s, disappeared on addition of $\left.\mathrm{D}_{2} \mathrm{O}\right)$. TLC: $R f 0.4$.

Hydrogenation of Curcumin (V) to Dihydrocurcumin (III), Hexahydrocurcumin (IV) and Octahydrocurcumin (Id) - A solution of $\mathrm{V}(50 \mathrm{mg})$ in $\mathrm{MeOH}(5 \mathrm{ml})$ was stirred with $\mathrm{PtO}_{2}(20 \mathrm{mg})$ for $20 \mathrm{~min}$ at room temperature under an $\mathrm{H}_{2}$ atmosphere, then the catalyst was removed by filtration and the filtrate was evaporated in vacuo. The product was subjected to preparative TLC to give yellow needles $(5 \mathrm{mg})$, which were identical with III on the basis of mixed melting point determination and TLC, MS and ${ }^{1} \mathrm{H}-\mathrm{NMR}$ comparisons.

Further hydrogenation of $\mathrm{V}(50 \mathrm{mg})$ for $9 \mathrm{~h}$ under the above conditions gave a mixture of oily products, which gave two spots on TLC. Separation of this mixture by preparative TLC afforded a colorless oil ( $20 \mathrm{mg}$ ), identical with Id on the basis of MS data, as the more polar component. In the ${ }^{13} \mathrm{C}-\mathrm{NMR}$ spectrum of Id, some carbons appeared as a pair of signals with the same multiplicity (the signal with stronger intensity is indicated in parentheses) as follows: ${ }^{13}$ C-NMR (acetone- $d_{6}$ ) $\delta: 32.3(31.9)(\mathrm{t}), 40.8(41.1)(\mathrm{t}), 44.7(44.2)(\mathrm{t}), 56.3(\mathrm{q}), 68.3(71.3)(\mathrm{d}), 113.1(\mathrm{~d}), 115.7(\mathrm{~d})$, $121.5(\mathrm{~d}), 134.9(134.8)(\mathrm{s}), 145.2(\mathrm{~s}), 148.2(\mathrm{~s}) .[\alpha]_{\mathrm{D}} 0^{\circ}(c=1.0, \mathrm{EtOH}) . \mathrm{UV} \lambda_{\max }^{\mathrm{EtOH}} \mathrm{nm}(\varepsilon): 225,282$, UV $\lambda_{\max }^{\mathrm{EtOH}+\mathrm{NaOH}} \mathrm{nm}$ : 243, 296. MS $m / z(\%): 376\left(\mathrm{M}^{+}, 7\right), 358(9), 340(3), 151$ (9), 150 (7), $138(24), 137$ (100). TLC: Rf 0.1.

The less polar colorless oil $(20 \mathrm{mg}),[\alpha]_{\mathrm{D}} 0^{\circ}(c=1.0, \mathrm{EtOH})$, was identical with IV on the basis of TLC, MS, ${ }^{1} \mathrm{H}-$ and ${ }^{13} \mathrm{C}-\mathrm{NMR}$ comparisons.

(3R,5R)-1-(4-Hydroxyphenyl)-7-phenylheptane-3,5-diol (VIa): Colorless needles, mp $109-111^{\circ} \mathrm{C},[\alpha]_{\mathrm{D}}+8.3^{\circ}$ $\left(c=0.39, \mathrm{CHCl}_{3}\right)$. UV $\lambda_{\max }^{\mathrm{EtOH}} \mathrm{nm}(\varepsilon): 215(8000), 225(8500), 275(1500)$. UV $\lambda_{\max }^{\mathrm{EtOH}+\mathrm{NaOH}} \mathrm{nm}: 218,235,290 . \mathrm{MS} m / z$ $(\%): 300\left(\mathrm{M}^{+}, 0.3\right.$, Calcd for $\mathrm{C}_{19} \mathrm{H}_{24} \mathrm{O}_{3} 300.1724$; Found 300.1749), 282 (7), 264 (0.7), $121(6), 120(16), 107(100), 105$ (10), 91 (70), 77 (23). IR $\left(\mathrm{CHCl}_{3}\right) \mathrm{cm}^{-1}: 3600,2940,1615,1600,1520,1500,1455,1430,1380,1330,1255,1170 .{ }^{1} \mathrm{H}-$ NMR (acetone- $\left.d_{6}\right) \delta: 1.59(2 \mathrm{H}, \mathrm{t}, J=6 \mathrm{~Hz}), 1.66-1.79(4 \mathrm{H}, \mathrm{m}), 2.50-2.87(4 \mathrm{H}, \mathrm{m}), 3.84-3.95(2 \mathrm{H}, \mathrm{m}), 6.73(2 \mathrm{H}, \mathrm{d}$, $J=8.5 \mathrm{~Hz}), 7.03(2 \mathrm{H}, \mathrm{d}, J=8.5 \mathrm{~Hz}), 7.18-7.29(5 \mathrm{H}, \mathrm{m}), 8.01\left(1 \mathrm{H}\right.$, br s, disappeared on addition of $\left.\mathrm{D}_{2} \mathrm{O}\right)$. TLC: $R f$ 0.3 .

Methylation of VIa to VIb-The method described above was employed with $2 \mathrm{mg}$ of VIa. The product was recrystallized from benzene-ethyl acetate to give VIb as colorless needles $(1.5 \mathrm{mg}), \mathrm{mp} 73-76^{\circ} \mathrm{C}$. MS $\mathrm{m} / z(\%): 314^{\circ}$ (0.02), 296 (0.9), 278 (8), 135 (3), 134 (10), 121 (100), $105(5), 91(38), 77(12) .{ }^{1} \mathrm{H}-\mathrm{NMR}\left(\mathrm{CDCl}_{3}\right) \delta: 1.67(2 \mathrm{H}, \mathrm{t}$, $J=5.5 \mathrm{~Hz}), 1.70-1.91(4 \mathrm{H}, \mathrm{m}), 2.56-2.82(4 \mathrm{H}, \mathrm{m}), 3.78(3 \mathrm{H}, \mathrm{s}), 3.94-4.02(2 \mathrm{H}, \mathrm{m}), 6.83(2 \mathrm{H}, \mathrm{d}, J=8.5 \mathrm{~Hz}), 7.11$ $(2 \mathrm{H}, \mathrm{d}, J=8.5 \mathrm{~Hz}), 7.19(3 \mathrm{H}, \mathrm{d}, J=7.5 \mathrm{~Hz}), 7.29(2 \mathrm{H}, \mathrm{d}, J=7.5 \mathrm{~Hz})$.

Bis-p-dimethylaminobenzoate (VIc) of VIb The method described above was employed with $1 \mathrm{mg}$ of VIb. The product was purified by column chromatography (benzene: AcOEt $=5: 1$ ) and preparative TLC (benzene: $\left.\mathrm{CHCl}_{3}: \mathrm{CH}_{3} \mathrm{CN}=2: 1: 1\right)$ to give VIc as a colorless oil $(0.5 \mathrm{mg}),[\alpha]_{\mathrm{D}}-80^{\circ}(c=0.03, \mathrm{EtOH})$. UV $\lambda_{\max }^{\mathrm{EtOH}} \mathrm{nm}(\varepsilon): 225$ (35000), 311 (50000). CD $(c=0.0008, \mathrm{EtOH}): \Delta \varepsilon=-30$ (318) (negative maximum), $\Delta \varepsilon=0(306), \Delta \varepsilon=+20(292)$ (positive maximum). MS $m / z(\%): 608\left(\mathrm{M}^{+}, 1.2\right), 443$ (7.5), $278(19), 174(31), 165$ (96), 164 (63), 148 (71), 147 (26), $134(35), 121(100), 91(34) .{ }^{1} \mathrm{H}=\mathrm{NMR}\left(\mathrm{CDCl}_{3}\right) \delta: 1.89-2.13(6 \mathrm{H}, \mathrm{m}), 2.59-2.78(4 \mathrm{H}, \mathrm{m}), 3.02(12 \mathrm{H}, \mathrm{s}), 3.75(3 \mathrm{H}$, $\mathrm{m}), 5.23(2 \mathrm{H}, \mathrm{br} \mathrm{s}), 6.57(4 \mathrm{H}, \mathrm{d}, J=9 \mathrm{~Hz}), 6.79(2 \mathrm{H}, \mathrm{d}, J=8 \mathrm{~Hz}), 7.05(2 \mathrm{H}, \mathrm{d}, J=8 \mathrm{~Hz}), 7.1-7.2(5 \mathrm{H}, \mathrm{m}), 7.83(4 \mathrm{H}$, 
d, $J=9 \mathrm{~Hz})$.

Acknowledgement We would like to thank Mr. S. Hemmi, P. T. EISAI INDONESIA and Dr. K. Kagei, Tsukuba Research Laboratories, Eisai Co., Ltd. for the supply of C. xanthorrhiza.

\section{References}

1) M. Kuroyanagi and S. Natori, Yakugaku Zasshi, 90, 1467 (1970).

2) H. Itokawa, M. Morita and S. Mihashi, Chem. Pharm. Bull., 29, 2383 (1981).

3) F. Kiuchi, M. Shibuya and U. Sankawa, Chem. Pharm. Bull., 30, 2279 (1982).

4) F. W. Wehrli and T. Wirthlin, "Interpretation of Carbon-13 NMR Spectra," Heyden, London, 1976.

5) T. Hashimoto, M. Tori and Y. Asakawa, Chem. Pharm. Bull., 34, 1846 (1986).

6) N. Harada and K. Nakanishi, Accounts Chem. Res., 5, 257 (1972).

7) V. Ravindranath and M. N. Satyanarayana, Phytochemistry, 19, 2031 (1980).

8) T. Murata, M. Shinohara and M. Miyamoto, Chem. Pharm. Bull., 20, 2291 (1972).

9) D. J. Harvey, J. Chromatogr., 212, 75 (1981).

10) H. Itokawa, H. Morita, I. Midorikawa, R. Aiyama and M. Morita, Chem. Pharm. Bull., 33, 4889 (1985).

11) M. Kuroyanagi, T. Noro, S. Fukushima, R. Aiyama, A. Ikuta, H. Itokawa and M. Morita, Chem. Pharm. Bull., 31, 1544 (1983); T. Inoue, T. Shinbori, M. Fujioka, K. Hashimoto and Y. Masada, Yakugaku Zasshi, 98, 1255 (1978).

12) American Cyanamid Co., Fr. Patent 1482866 (1967) [Chem. Abstr., 69, 19143v (1968)].

13) G. N. Vyas and N. M. Shah, "Organic Syntheses," Coll. Vol. IV, ed. by N. Rabjohn, John Wiley and Sons, Inc., New York, 1963, p. 836. 